\title{
Ocular Adnexal Lymphoma pNX TNM
} Finding v7

National Cancer Institute

\section{Source}

National Cancer Institute. Ocular Adnexal Lymphoma pNX TNM Finding v7. NCI

Thesaurus. Code C88848.

Involvement of lymph nodes not assessed. (from AJCC 7th Ed.) 